\title{
The effect of picroside II on the expressions of AQP4, MMP9 and COX2 in cerebral ischemic injury in rats
}

\author{
Xiaodan Li, Zhao Li, Tingting Wang, Meizeng Zhang, Haitao Pei ${ }^{\#}$ \\ Department of Neurology, Affiliated Hospital of Qingdao University Medical College, Qingdao, China \\ Email: lixiaodanqd@163.com, zhaoliqd2012@163.com, 61279652@.qq.com, zmzcmd@163.com,
}

Received 26 June 2013; revised 25 August 2013; accepted 30 August 2013

Copyright (C) 2013 Xiaodan Li et al. This is an open access article distributed under the Creative Commons Attribution License, which permits unrestricted use, distribution, and reproduction in any medium, provided the original work is properly cited.

\begin{abstract}
The aim is to study the neuroprotective effect and optimize the therapeutic dose and time window of picrosede II by orthogonal test in cerebral ischemic injury in rats. The forebrain ischemia models of rats were established by bilateral common carotid artery occlusion (BCCAO) methods. The successful models were randomly grouped according to orthogonal experimental design and treated by injecting picroside II intraperitonenally with different therapeutic dose at different ischemic time. The contents of aquaporins 4 (AQP4), matrix metalloproteinases 9 (MMP 9) and cyclooxygenase 2 (COX2) in brain tissue were determined by enzyme linked immunosorbent assay to evaluate the therapeutic effect of picroside II on cerebral ischemic injury. The results indicated that the best therapeutic time window and dose of picroside II in cerebral ischemic injury should be 1) ischemia $1.5 \mathrm{~h}$ with $20 \mathrm{mg} / \mathrm{kg}$ body weight according to the content of AQP4; 2) ischemia $2.0 \mathrm{~h}$ with 20 $\mathrm{mg} / \mathrm{kg}$ according to the content of MMP9; and 3) ischemia $1.5 \mathrm{~h}$ with $20 \mathrm{mg} / \mathrm{kg}$ according to the content of COX2 in brain tissue. It is concluded that the optimized therapeutic dose and time window is injecting picroside II peritonenally with $10-20 \mathrm{mg} / \mathrm{kg}$ body weight at ischemia $1.5-2.0 \mathrm{~h}$ in cerebral ischemic injury according to the principle of lowest therapeutic dose with longest time window.
\end{abstract}

Keywords: Picroside II; Cerebral Ischemia; Therapeutic Dose; Time Window; Rats

\section{INTRODUCTION}

In central nervous system (CNS), aquaporins 4(AQP4)

\footnotetext{
"Competing interests: The authors declare that they have no competing interests.

"Corresponding author.
}

mediates transportation of water across cell membranes [1]. Previous animal experiments proved that AQP4 expression increased in the cortex around the infarct area at cerebral ischemia $3 \mathrm{~h}$ in rats [2], and could be downregulated to attenuate cerebral edema by treating with picrosid II [3]. Matrix metalloproteinases 9 (MMP 9) could damage the blood-brain barrier (BBB) by degradeing the basement membrane and tight intercellular junction to induce cerebral edema in inflammatory reaction process, and also cause neuronal death and cerebral injury directly [4,5], while knockouting MMP9 gene could reduce cerebral injury obviously [6]. Some experiments proved that MMP9 expression increased after cerebral ischemia and be inhibited by picroside II [7] to attenuate inflammatory injury in cerebral ischemia. After cerebral ischemic injury, cyclooxygenase 2 (COX2) expression increased significantly in cortical and hippocampal neurons and glial cells [8], while COX2 gene knockouting reduced obviously the infarction volume in rats [9]. The author's research results shown that picroside II could inhibit the expressions of relative inflammatory factors in the ischemic penumbra $[10,11]$ and reduce infarction volume after cerebral ischemia in rats [12,13], and also explored primarily the therapeutic doses and time window of picroside II in treating cerebral ischemia $[14,15]$. This experiment aims to further explore the therapeutic doses and time window of picroside II in treating cerebral ischemia from three aspects of inflammatory reaction, BBB permeability and brain edema by measuring the contents of AQP4, MMP9 and COX2 in brain homogenates.

\section{MATERIALS AND METHODS}

\subsection{Animal Models}

This experiment was approved by the Ethics Committee of Qingdao University Medical College (QUMC 201109). The local legislation for ethics of experiment on animals 
and guidelines for the care and use of laboratory animals were followed in all animal procedures. Total of 30 adult healthy male Wistar rats, SPF grade, weight 230 - $250 \mathrm{~g}$, were supplied by the Experiment Animal Center of Qingdao Drug Inspection Institute (SCXK (Lu) 20100010). All animals were acclimatized for one week in the laboratory and allowed free access to food and water in a room temperature $\left(23^{\circ} \mathrm{C} \pm 2^{\circ} \mathrm{C}\right)$ and absolute diet $12 \mathrm{~h}$ before operation. Firstly, five rats were randomly assigned to sham-surgery group, and the rest 25 rats were anesthetized by injecting intraperitoneally $10 \%$ choral hydrate $(0.3 \mathrm{ml} / \mathrm{kg})$ and fixed in supine position to conduct aseptic operation to establish forebrain ischemia model by separating and ligating bilateral common carotid artery (BCCAO)[16]. The rectal temperature was maintained at $36^{\circ} \mathrm{C}-37^{\circ} \mathrm{C}$ during and after the operation. Four animals which still unawaked $2 \mathrm{~h}$ after operation or died were excluded and the 21 successful models were internalized into the experiment. Rats in the shamoperation group underwent the same surgical procedures except of occlusion of bilateral common carotid artery.

\subsection{Design and Group}

Of 21 successful modes, five cases were randomly assigned to model group and the rest 16 cases to the treatment group, which were randomly subgrouped according to the principle of orthogonal experimental design of $\left[L_{16}\left(4^{5}\right)\right]$ consisting of two impact factors with four impact levels. The impact factor $\mathrm{A}$ is the therapeutic time widow designed four levels of $1.0 \mathrm{~h}, 1.5 \mathrm{~h}, 2.0 \mathrm{~h}, 2.5 \mathrm{~h}$ after ischemia. The impact factor $\mathrm{B}$ is the therapeutic drug dose which has four levels as $5 \mathrm{mg} / \mathrm{kg}, 10 \mathrm{mg} / \mathrm{kg}, 20$ $\mathrm{mg} / \mathrm{kg}$ and $40 \mathrm{mg} / \mathrm{kg}$ body weight (Table 1).

\subsection{Intervention Methods}

Picroside II (molecular formular: $\mathrm{C}_{23} \mathrm{H}_{28} \mathrm{O}_{13}$, molecular weight: 512) was provided by Tianjing Kuiqing Medical Technology (CAS No: 39012-20-9, purity > 98\%). Picroside II was diluted into $1 \%$ solution with $0.9 \mathrm{~g} / \mathrm{L}$ sodium chloride and injected intraperitoneally according to the corresponding designed dose at designed time in the orthogonal layout $\left[L_{16}\left(4^{5}\right)\right]$. Rats in the sham operation group and model group were intraperitoneally

Table 1. Orthogonal experimental design of $\left[\mathrm{L}_{16}\left(4^{5}\right)\right]$.

\begin{tabular}{ccccc}
\hline $\begin{array}{c}\text { Therapeutic } \\
\text { dose }\end{array}$ & $\begin{array}{c}\text { Ischemia } \\
1.0 \mathrm{~h}(\mathrm{~A} 1)\end{array}$ & $\begin{array}{c}\text { Ischemia } \\
1.5 \mathrm{~h}(\mathrm{~A} 2)\end{array}$ & $\begin{array}{c}\text { Ischemia } \\
2.0 \mathrm{~h}(\mathrm{~A} 3)\end{array}$ & $\begin{array}{c}\text { Ischemia } \\
2.5 \mathrm{~h}(\mathrm{~A} 4)\end{array}$ \\
$5 \mathrm{mg} / \mathrm{kg}(\mathrm{B} 1)$ & $1.0 \times 5$ & $1.5 \times 5$ & $2.0 \times 5$ & $2.5 \times 5$ \\
$10 \mathrm{mg} / \mathrm{kg}(\mathrm{B} 2)$ & $1.0 \times 10$ & $1.5 \times 10$ & $2.0 \times 10$ & $2.5 \times 10$ \\
$20 \mathrm{mg} / \mathrm{kg}$ (B3) & $1.0 \times 20$ & $1.5 \times 20$ & $2.0 \times 20$ & $2.5 \times 20$ \\
$40 \mathrm{mg} / \mathrm{kg}$ (B4) & $1.0 \times 40$ & $1.5 \times 40$ & $2.0 \times 40$ & $2.5 \times 40$ \\
\hline
\end{tabular}

injected same dose of $9 \mathrm{~g} / \mathrm{L}$ sodium chloride after operation $2 \mathrm{~h}$ (Table 1).

\subsection{Sample Collection}

After $12 \mathrm{~h}$ following the administration, rats were anesthetized by injecting intraperitoneally $10 \%$ choral hydrate $(0.3 \mathrm{ml} / \mathrm{kg})$ and perfused with $200 \mathrm{ml}$ of normal sodium solution from the heart into the aorta. The brains were completely taken out, and olfactory bulb and prefrontal brain were removed. $500 \mathrm{mg}$ forebrain ischemic tissue were cut backward from the optic chiasm (Bregma $0.00 \mathrm{~mm}$ ) put into pre-cooling mortar to grind into powder. Added cell lysis solution ( $500 \mu \mathrm{l}$ cell lysis solution + $5 \mu$ l PMSF, No. P0013, Biyuntian Biotechnology Co. Ltd.) according to $1: 3$ proportion after grinding into powder in the pre-cooling mortar. The ultrasonic slurry was centrifugated with $12,000 \mathrm{r} / \mathrm{min}$ for $10 \mathrm{~min}$ at $4^{\circ} \mathrm{C}$ by freezing centrifuge (Eppendorf 5081, Germany). Then collected the supernatant to determine the protein concentration by BCA assay (Wuhan Boster Biological Engineering Co. Ltd.) and stored at $-20^{\circ} \mathrm{C}$ for later use.

\subsection{ELISA Assay}

The concents of AQP4, MMP9 and COX-2 in brain tissue were determined by enzyme linked immunosorbent assay kits of AQP4 (E02A0467), MMP9 (E02M0329) and COX-2 (E02C0080) provided by Blue Gene Co. Ltd. According to the instructions of kits, remelte the brain tissue homogenate at room temperature and centrifuge again to took supernatant $100 \mu \mathrm{l}$ for later use. The procedures: 1) Secure the desired numbers of coated wells in the holder then add $100 \mu$ of standards or samples to the appropriate well in the antibody pre-coated microtiter plate. Add $100 \mu$ l of PBS (pH 7.0 - 7.2) in the blank control well. 2) Dispense $10 \mu \mathrm{l}$ of balance solution into 100 $\mu \mathrm{l}$ specimens, mix well. 3) Add $50 \mu \mathrm{l}$ of conjugate to each well (Not blank control well). Mix well. Mixing well in this step is important. Cover and incubate the plate for 1 hour at $37^{\circ} \mathrm{C}$. 4) Wash the microtiter plate automatically 5 times with diluted wash solution (350 $400 \mu \mathrm{l} /$ well/wash) using an auto washer. After washing, dry the plate as above. It is recommended that the washer be set for a soaking time of 10 seconds and shaking time of 5 seconds between each wash. 5) Add $50 \mu$ l substrate A and $50 \mu \mathrm{l}$ substrate B to each well including blank control well, subsequently. Cover and incubate for 10 minutes at $25^{\circ} \mathrm{C}$ (Avoid sunlight). 6) Add $50 \mu \mathrm{l}$ of stop solution to each well including blank control well. Mix well. 7) Determine the optical density (OD) at $450 \mathrm{~nm}$ using a microplate reader immediately. 8) Calculating results: a) The standard curve is used to determine the amount of samples. b) First, average the duplicate readings for each standard and sample. All OD values are 
subtracted by the mean value of blank control before result interpretation. c) Construct a standard curve by plotting the average OD for each standard on the vertical (Y) axis against the concentration on the horizontal (X) axis, and draw a best fit curve e using graph paper or statistical software to generate a four paramater logistic (4-PL) curve-fit or logit-log linear regression curve. An $\mathrm{x}$-axis for the optical density and a $\mathrm{y}$-axis for the concentration is also a choice. The data may be linearized by plotting the $\log$ of the concentrations versus the log of the OD and the best fit line can be determined by regression analysis. d) Calculate the concentration of samples corresponding to the mean absorbance from the standard curve. e) The sensitivity in this assay is $0.1 \mathrm{ng} / \mathrm{ml}$.

\subsection{Statistical Analysis}

SPSS 17.0 software was used for data statistical analysis. According to the result, multi-group comparison was made by analysis of orthogonal test whether different level of administrating time and therapeutic dose had significant deviation or not, and whether their interaction on each detected index had significant deviation or not, meanwhile to explore the best therapeutic drug dose and the therapeutic time window.

\section{RESULTS}

In sham group, the contents of AQP4, MMP9 and COX2 in brain tissue were significantly lower than those in model group $(t=31.38-43.54, P<0.01)$. In treatment group, the contents of AQP4, MMP9 and COX2 in brain tissue were significantly lower than those in model group $(t=4.58-9.60, P<0.01)$. Shown as Tables 2 and 3.

\subsection{AQP4 (Table 4)}

There were significant influences of different levels of administration time (factor A), drug doses (factor B) and the interaction of time-dose (factor $\mathrm{C}$ ) on the concentration of AQP4 in brain tissue after ischemia injury $(P=$ $0.01-0.03$ ). All data were compared in pairs by the way of least significant difference (LSD) and the results indicated that no significant difference $(P>0.05)$ between the concentration of AQP4 at administration $1 \mathrm{~h}$ (A1) and $2 \mathrm{~h}$ (A3), while there were significant differences be-

Table 2. The results of AQP4, MMP9 and COX2 (ng/ml).

\begin{tabular}{ccccc}
\hline groups & $\mathrm{n}$ & AQP4 & MMP9 & COX2 \\
\hline Sham group & 5 & $0.613 \pm 0.062$ & $0.428 \pm 0.082$ & $0.244 \pm 0.043$ \\
Model group & 5 & $1.612 \pm 0.203^{\mathrm{a}}$ & $1.212 \pm 0.116^{\mathrm{a}}$ & $0.768 \pm 0.065^{\mathrm{a}}$ \\
Treatment group & 16 & $1.105 \pm 0.191^{\mathrm{b}}$ & $0.803 \pm 0.163^{\mathrm{b}}$ & $0.581 \pm 0.094^{\mathrm{b}}$ \\
\hline
\end{tabular}

${ }^{\mathrm{a}}$ Compare with sham group, $P<0.01 ;{ }^{\mathrm{b}}$ compare with model group, $P<0.01$.
Table 3. $\left[\mathrm{L}_{16}\left(4^{5}\right)\right]$ orthogonal layout and the results.

\begin{tabular}{|c|c|c|c|c|c|c|c|c|}
\hline \multirow{2}{*}{$\begin{array}{l}\text { Test } \\
\text { NO. }\end{array}$} & \multicolumn{5}{|c|}{ Rank NO. } & \multirow{2}{*}{$\begin{array}{c}\text { AQP4 } \\
\mathrm{ng} / \mathrm{ml}\end{array}$} & \multirow{2}{*}{$\begin{array}{c}\text { MMP9 } \\
\mathrm{ng} / \mathrm{ml}\end{array}$} & \multirow{2}{*}{$\begin{array}{c}\mathrm{COX} 2 \\
\mathrm{ng} / \mathrm{ml}\end{array}$} \\
\hline & A & B & $\mathrm{C}$ & $\mathrm{D}$ & $\mathrm{E}$ & & & \\
\hline 1 & 1 & 1 & 1 & 1 & 1 & 1.081 & 0.738 & 0.530 \\
\hline 2 & 1 & 2 & 2 & 2 & 2 & 1.103 & 0.757 & 0.492 \\
\hline 3 & 1 & 3 & 3 & 3 & 3 & 1.105 & 0.729 & 0.550 \\
\hline 4 & 1 & 4 & 4 & 4 & 4 & 1.109 & 0.739 & 0.608 \\
\hline 5 & 2 & 1 & 2 & 3 & 4 & 1.071 & 0.877 & 0.584 \\
\hline 6 & 2 & 2 & 1 & 4 & 3 & 0.832 & 0.616 & 0.451 \\
\hline 7 & 2 & 3 & 4 & 1 & 2 & 0.773 & 0.616 & 0.413 \\
\hline 8 & 2 & 4 & 3 & 2 & 1 & 1.039 & 0.785 & 0.550 \\
\hline 9 & 3 & 1 & 3 & 4 & 2 & 1.263 & 0.766 & 0.562 \\
\hline 10 & 3 & 2 & 4 & 3 & 1 & 0.909 & 0.732 & 0.532 \\
\hline 11 & 3 & 3 & 1 & 2 & 4 & 0.862 & 0.636 & 0.544 \\
\hline 12 & 3 & 4 & 2 & 1 & 3 & 1.205 & 0.722 & 0.684 \\
\hline 13 & 4 & 1 & 4 & 2 & 3 & 1.356 & 1.133 & 0.706 \\
\hline 14 & 4 & 2 & 3 & 1 & 4 & 1.291 & 0.912 & 0.710 \\
\hline 15 & 4 & 3 & 2 & 4 & 1 & 1.246 & 0.927 & 0.658 \\
\hline 16 & 4 & 4 & 1 & 3 & 2 & 1.434 & 1.165 & 0.726 \\
\hline I & 4.398 & 4.771 & 4.209 & 4.350 & 4.275 & 17.679 & 12.850 & 9.300 \\
\hline II & 3.715 & 4.135 & 4.625 & 4.360 & 4573 & & & \\
\hline III & 4.239 & 3.986 & 4.698 & 4.519 & 4.498 & & & \\
\hline IV & 5327 & 4.787 & 4.147 & 4.450 & 4.333 & & & \\
\hline SS & 0.338 & 0.132 & 0.060 & 0.140 & 0.060 & & & \\
\hline
\end{tabular}

Table 4. ANOVA of AQP4 in brain tissue.

\begin{tabular}{cccccc}
\hline Sources of variation & SS & df & MS & $F$ & $P$ \\
Ischemic time & 0.338 & 3 & 0.113 & 35.01 & 0.01 \\
Therapeutic dose & 0.132 & 3 & 0.044 & 13.65 & 0.01 \\
Time $\times$ dose & 0.060 & 3 & 0.020 & 6.17 & 0.03 \\
Error & 0.019 & 6 & 0.003 & & \\
\hline
\end{tabular}

tween the rest time levels of AQP4 concentrations $(P<$ $0.05)$. There was no significant difference between the concentration of AQP 4 between drug dose of $5 \mathrm{mg} / \mathrm{kg}$ (B1) and $40 \mathrm{mg} / \mathrm{kg}$ (B4), $10 \mathrm{mg} / \mathrm{kg}$ (B2) and $20 \mathrm{mg} / \mathrm{kg}$ (B3) $(P>0.05)$, but the significant differences existed among the other levels of doses $(P<0.05)$. According to the principle of lowest therapeutic dose with longest time window, the optimized therapeutic dose and time window maybe injecting picroside II peritonenally with 20 
$\mathrm{mg} / \mathrm{kg}$ body weight at ischemia $1.5 \mathrm{~h}$ in cerebral ischemic injury, which is the combination of A2B3.

\subsection{MMP9 (Table 5)}

There were significant differences between different therapeutic time (A) on the concentration of MMP9 in brain tissue following cerebral ischemia $(\mathrm{P}<0.05)$, but no significant difference existed between drug doses (B) and the interaction of time-dose on the concentration of MMP9 in brain tissue $(P>0.05)$. The results of LSD showed that no significance $(P>0.05)$ between the concentration of MMP9 at administration time $1.0 \mathrm{~h}$ (A1) and $1.5 \mathrm{~h}$ (A2), $1.0 \mathrm{~h}$ (A1) and $2.0 \mathrm{~h}$ (A3), $1.5 \mathrm{~h}$ (A2) and $2.0 \mathrm{~h}$ (A3), while there were significant differences between the other administration time levels $(P<0.05)$. There were significant differences $(P<0.05)$ between the concentration of MMP9 in a drug dose of $5 \mathrm{mg} / \mathrm{kg}$ (B1) and $20 \mathrm{mg} / \mathrm{kg}$ (B3), and no significant difference found between that of the other doses $(P>0.05)$. From the principle of lowest therapeutic dose with longest time window, the combination of $\mathrm{A} 3 \mathrm{~B} 3$ is the best, that is injecting picroside II peritonenally with $20 \mathrm{mg} / \mathrm{kg}$ body weight at ischemia $2 \mathrm{~h}$ in cerebral ischemic injury.

\subsection{COX2 (Table 6)}

There were significant influences of administration time (A) on the concentration of COX2 in brain tissue following cerebral ischemia $(P<0.05)$, but no significant difference existed between drug doses (B) and the interaction of time-dose $(C)$ on the concentration of COX2 in brain tissue $(P>0.05)$. The result of LSD proved that no significant difference $(P>0.05)$ between the concentration of COX2 at administration time $1.0 \mathrm{~h}$ (A1) and $1.5 \mathrm{~h}$ (A2), $1.0 \mathrm{~h} \mathrm{(A1)} \mathrm{and} 2.0 \mathrm{~h}$ (A3), but there were signifi-

Table 5. ANOVA of MMP9 in brain tissue.

\begin{tabular}{cccccc}
\hline Sources of variation & SS & df & MS & $F$ & $P$ \\
\hline Ischemic time & 0.286 & 3 & 0.095 & 12.49 & 0.01 \\
Therapeutic dose & 0.065 & 3 & 0.022 & 2.85 & 0.13 \\
Time $\times$ dose & 0.002 & 3 & 0.001 & 0.10 & 0.96 \\
Error & 0.046 & 6 & 0.008 & & \\
\hline
\end{tabular}

Table 6. ANOVA of COX2 in brain tissue.

\begin{tabular}{cccccc}
\hline Sources of variation & SS & df & MS & $F$ & $P$ \\
\hline Ischemic time & 0.088 & 3 & 0.029 & 14.96 & 0.01 \\
Therapeutic dose & 0.027 & 3 & 0.009 & 4.55 & 0.06 \\
Time $\times$ dose & 0.005 & 3 & 0.002 & 0.88 & 0.50 \\
Error & 0.012 & 6 & 0.002 & & \\
\hline
\end{tabular}

cant differences between the other time levels $(P<0.05)$. There were significant differences $(P<0.05)$ between the concentration of COX2 in drug doses of $10 \mathrm{mg} / \mathrm{kg}$ (B2) and $40 \mathrm{mg} / \mathrm{kg}$ (B4), $20 \mathrm{mg} / \mathrm{kg}$ (B3) and $40 \mathrm{mg} / \mathrm{kg}$ (B4), while no significant difference between that in the other doses $(P>0.05)$. From the principle of lowest therapeutic dose with longest time window, the combination of $\mathrm{A} 2 \mathrm{~B} 3$ is the best, that is injecting picroside II peritonenally with $20 \mathrm{mg} / \mathrm{kg}$ body weight at ischemia 1.5 $\mathrm{h}$ in cerebral ischemic injury.

\section{DISCUSSION}

AQP4, mediating water transportation across cells and consisting of 4 subunits, is a member of the water channel protein family [1]. It is a major specific water channel protein in CNS, participating in regulating the activeity of the water channel [17]. It's distributed within the glial and ependymal cell membrane in brain tissue and myeloid tissue [18]. In the early stage of cerebral ischemia, AQP4 expression increased in the glial cell, especially in the foot processes surrounding capillary vessels, which promoted the occurrence of cerebral edema [19]. AQP4 gene knockout plays a protective effect on acute cerebral ischemic injury [20]. Under normal conditions, MMP9 expression is very low, and various cytokines and inflammatory factors are released and combine with the binding site of MMP9 after cerebral ischemia, which contributes to increasing and activating the expression of MMP9 [21]. The activated MMP9 degrades and damages the basement membranes and tight intercellular junction, which resulted in the compromise of the BBB and secondary cerebral edema. It also could result in neuronal death and cerebral injury directly $[4,5]$. COX is one of nuclear signal transporting targets and expresses in some cells such as neuron in a low level under normal conditionst. COX expression increases following cerebral ischemia, which is considered as an important target of treating neuronal injury [22].

This experiment was carried out according to orthogonal table of $\left[\mathrm{L}_{16}\left(4^{5}\right)\right]$, and was designed four time points at $1 \mathrm{~h}, 1.5 \mathrm{~h}, 2 \mathrm{~h}$ and $2.5 \mathrm{~h}$ after brain ischemic injury. The rats were injected intraperitoneally picroside II with four therapeutic doses of $5 \mathrm{mg} / \mathrm{kg}, 10 \mathrm{mg} / \mathrm{kg}, 20$ $\mathrm{mg} / \mathrm{kg}$ and $40 \mathrm{mg} / \mathrm{kg}$. The concentrations of AQP4, MMP9 and COX2 in brain tissue were determined to explore the best therapeutic dose and best time window of picroside II in treating cerebral ischemic injury. The results indicated that there were significant differences between administration time and therapeutic doses of picroide II in treating cerebral ischemia, and the best combination is not accordant by different indexes. Considering minimization of medication dose and maximizetion of therapeutic time window, it is suggested the best choose of $\mathrm{A} 2 \mathrm{~B} 2$ and $\mathrm{A} 3 \mathrm{~B} 3$ combination, that is injecting 
picroside II intraperitonenally with $10-20 \mathrm{mg} / \mathrm{kg}$ body weight at ischemia $1.5-2.0 \mathrm{~h}$ in cerebral ischemic injury. Because the mechanism of cerebral ischemic injury is very complicated [23] and only above indexes was observed in this experiment, the results could not possibly all be right. So the exact mechanism, the best therapeutic dose and administration time of picroside II need to be further studied in further experiments.

\section{CONCLUSION}

This paper suggested that the best therapeutic dose and time window of picroside II in treating cerebral ischemic injury should be injected picroside II intraperitoneally with $10-20 \mathrm{mg} / \mathrm{kg}$ body weight at ischemia $1.5-2.0 \mathrm{~h}$ according to the principle of minimization of medication dose and maximization of therapeutic time.

\section{ACKNOWLEDGEMENTS}

This study was supported by grant-in-aids for The National Natural Science Foundation of China (grant No. 81041092 and No. 81274116).

\section{REFERENCES}

[1] Zelenina, M. (2010) Regulation of brain aquaporins. Neurochemistry International, 57, 468-488. http://dx.doi.org/10.1016/j.neuint.2010.03.022

[2] Sun, W., Su, Z.Q., Liu, J.F., Sheng, L., Yang, K.P. and Zhao, J.L. (2009) The effect of Kir4.1 and AQP4 in focal cerebral ischemia reperfusion injury rats. Chinese Journal of NeuroMed, 8, 484-487.

http://dx.doi.org/10.3760/cma.j.issn.1671-8925.2 009.05 .013

[3] Li, Z., Xu, X.Y., Li, Q., Zhang, M.Z. and Shen, W. (2010) Protective mechanisms of picroside on AQP4 in rat model of MCAO/R. Neural Regeneration Research, 5, 411-416.

[4] Tayebjee, M.H., Nadar, S., Blann, A.D., Gareth Beevers, D., MacFadyen, R.J. and Lip, G.Y. (2004) Matrix metalloproteinase-9 and tissue inhibitor of metalloproteinase-1 in hypertension and their relationship to cardiovascular risk and treatment: A substudy of the Anglo-Scandinavian Cardiac Outcomes Trial (ASCOT). American Journal of Hypertension, 17, 764-769. http://dx.doi.org/10.1016/S0895-7061(04)00855-6

[5] Gu, Z., Cui, J., Brown, S., Fridman, R., Mobashery, S., Strongin, A.Y. and Lipton, SA. (2005) A highly specific inhibitor of matrix metalloproteinase-9 rescues laminin from proteolysis and neurons from apoptosis in transient focal cerebral ischemia. Journal of Neuroscience, 25, 6401-6408. http://dx.doi.org/10.1523/JNEUROSCI.1563-05.2005

[6] Yang, Y., Estrada, E.Y., Thompson, J.F., Liu, W. and Rosenberg, G.A. (2007) Matrix metalloproteinase mediated disruption of tight junction proteins in cerebral vessels is reversed by synthetic matrix metalloproteinase inhibitor in focal ischemia in rat. Journal of Cerebral Blood
Flow \& Metabolism, 27, 697-709.

[7] Li, X., Xu, X.Y., Li, Z., Guo, Y.L. and Li, Q. (2010) Picroside II down-regulates matrix metalloproteinase-9 expression following cerebral ischemia/reperfusion injury in rats. Neural Regeneration Research, 5, 1403-1407. http://dx.doi.org/10.3969/j.issn.1673-5374.2010.18.007

[8] Kim, S.S., Kong, P.J., Kim, B.S., Sheen, D.H., Nam, S.Y. and Chun, W. (2004) Inhibitory action of minocycline on lipopolysaccharide-induced release of nitric oxide and prostaglandin E2 in BV2 microglial cells. Archives of Pharmacal Research, 27, 314-318. http://dx.doi.org/10.1007/BF02980066

[9] Luo, Y.M., Qin, Z. and Chen, J. (2001) Protective effects of COX2 gene knockout on brain from ischemic injury in mice. Chinese Journal of Geriatric Cardiovascular and Cerebrovascular Diseases, 3, 338-340. http://dx.doi.org/10.3969/j.issn.1009-0126.2001.05.01 $\underline{5}$

[10] Li, Z., Li, Q., Shen, W. and Guo, Y.L. (2010) The interferring effects of picroside II on the expressions of $\mathrm{NF}-\kappa \mathrm{B}$ and $\mathrm{I}-\kappa \mathrm{B}$ following cerebral ischemia reperfusion injury in rats. Chinese Pharmacological Bulletin, 26, 5255.

[11] Guo, Y.L., Shen, W., Du, F., et al. (2010) Effect of picroside II on expressions of TLR4 and NFKB in rats with cerebral ischemia reperfusion injury. Chinese Journal of Integrated Traditional and Western Medicine, 31, 58-61.

[12] Li, Z., Li, Q., Guo, Y.L., Qin, L.H. and Luan, L.J. (2010) Intervention effects of picroside II in cerebral ischemic injury rats. Acta Anthropologica Sinica, 41, 9-12.

[13] Li, Q., Guo, Y.-L., Li, Z. and Xu, X.Y. (2010) The interference of picroside II on the expressions of Caspase-3 and PARP following cerebral ischemia reperfusion injury in rats. Chinese Pharmacological Bulletin, 26, 342-345.

[14] Li, H.-Y., Zhao, L., Su, X., Pei, H.T., Zhang, M.Z., Xin, H. and Guo, Y.L. (2010) Primary study on the best therapeutic dose and time window of picroside II in cerebral ischemic injury in rats. Chinese Pharmacological Bulletin, 28, 549-553.

[15] Pei, H.T., Su, X., Zhao, L., Li, H.Y., Guo, Y.L., Zhang, M.Z. and Xin, H. (2012) Primary study for the therapeutic dose and time window of picroside II in treating cerebral ischemic injury in rats. International Journal of Molecular Sciences, 13, 2551-2562.

http://dx.doi.org/10.3390/ijms13032551

[16] Márquez-Martín, A., Jiménez-Altayó, F., Dantas, A.P., Caracuel, L., Planas, A.M. and Vila, E. (2012) Middle cerebral artery alterations in a rat chronic hypoperfusion model. Journal of Applied Physiology, 112, 511-518. http://dx.doi.org/10.1152/japplphysiol.00998.2011

[17] Masato, Y. (2009) Regulation, structure and function of brain aquaporin. Rinsho Shinkeigaku, 49, 786-788. http://dx.doi.org/10.5692/clinicalneurol.49.786

[18] Yang, M., Gao, F., Liu, H., Yu, W.H., He, G.Q., Zhuo, F., Qiu, G.P. and Sun, S.Q. (2011) Immunolocalization of aquaporins in rat brain. Anatomia, Histologia, Embryologia, 40, 299-306.

http://dx.doi.org/10.1111/j.1439-0264.2011.01070.x 
[19] Yasui, M. (2011) Aquaporin from basic to clinical medicine: roles in brain edema. No To Hattatsu, 43, 191-194.

[20] Shi, W.Z., Zhao, C.Z., Zhao, B., Zheng, X.L., Fang, S.H., Lu, Y.B., Zhang, W.P., Chen, Z. and Wei, E.Q. (2012) Aquaporin-4 deficiency attenuates acute lesions but aggravates delayed lesions and microgliosis after cryoinjury to mouse brain. Neuroscience Bulletin, 28, 61-68. http://dx.doi.org/10.1007/s12264-012-1063-7

[21] Rosenberg, G.A., Cunningham, L.A., Wallace, J., Alexander, S., Estrada, E.Y., Grossetete, M., Razhagi, A., Miller, K. and Gearing, A. (2001) Immunohistochemistry of matrix metalloproteinases in reperfusion injury to rat brain: Activation of MMP-9 linked to stromelysin-1 and microglia in cell cultures. Brain Research, 893, 104-112. http://dx.doi.org/10.1016/S0006-8993(00)03294-7

[22] Mehta, S.L., Manhas, N. and Raghubir, R. (2007) Molecular targets in cerebral ischemia for developing novel therapeutics. Brain Research Reviews, 54, 34-66.

[23] Guo, Y.L., Xu, X.Y., Li, Q., et al. (2010) Anti-inflammation effects of picroside II in cerebral ischemic injury rats. Behavioral Brain Function, 6, 43-53. http://dx.doi.org/10.1186/1744-9081-6-43 